\title{
A structured approach to pastoral care and poverty
}

\author{
Authors: \\ Johan Janse van Rensburg ${ }^{1}$ \\ Johann Breed ${ }^{2}$ \\ Affiliations: \\ ${ }^{1}$ Department of Practical \\ Theology, University of the \\ Free State, South Africa \\ ${ }^{2}$ Local Government \\ Consultant, South Africa \\ Correspondence to: \\ Johan Janse van Rensburg \\ Email: \\ jjvanr@yebo.co.za \\ Postal address: \\ PO Box 339, Bloemfontein \\ 9300, South Africa \\ Dates: \\ Received: 10 Jan. 2011 \\ Accepted: 14 Apr. 2011 \\ Published: 13 July 2011 \\ How to cite this article: \\ Janse van Rensburg, J. \& \\ Breed, J., 2011, 'A structured \\ approach to pastoral care \\ and poverty', Verbum et \\ Ecclesia 32(1), Art. \#490, \\ 11 pages. doi:10.4102/ \\ ve.v32i1.490

\section{Note:} \\ This article is subsidised by \\ the National Research Fund \\ and builds on two previous \\ articles published by Johan \\ Janse van Rensburg (2009 \& \\ 2010).
}

C 2011. The Authors. Licensee: AOSIS OpenJournals. This work is licensed under the Creative Commons Attribution License.
Although the plight of the poor and Christian benevolence is a topic often discussed in scientific and popular literature, the existing research is not nearly enough to address the many complicated issues surrounding the subject. Many reasons for this sad state of affairs may exist, one being the lack of the necessary skills to apply biblical and economic principles in order to make a marked difference. This article presented a biblical perspective on the caring of the poor and suggested a few contextual principles for pastoral counselling. Forces were joined with economic insights and the experience of Local Economic Development to empower the church to make a substantial difference to the plight of the poor. This approach could give structure to efforts that often achieve very little in terms of lasting results.

\section{Introduction}

It seems natural that the two themes, pastoral care and poverty should belong together. Yet, in practice this is not always the case. Armet (1997:17) justifiably concludes that an evangelical focus on 'saving souls' has been largely irrelevant amidst horrendous social ills. This happens when the immediate needs created by poverty are overlooked. On the other hand, it is also true that the poor are often helped with acts of benevolence whilst the pastoral care for the poor barely exists. From a case study performed by Verster (1997) we may conclude that the pastoral process predominantly consist of prayer and Scripture reading. However, the one or two visits with prayer and Scripture reading can barely be called pastoral care. True pastoral care should be a holistic involvement with the person in all his or her spiritual and physical needs. Many reasons may be presented, one being that the pastor lacks knowledge, technical skills or motivation.

There can be little doubt that ecclesiastical efforts to significantly address the problem of poverty have not been as successful in the long run as could be hoped for. This does not mean that the many efforts throughout the centuries have been in vain. However, it seems as though the problem of poverty and its many consequences have multiplied worldwide. Pressure is mounting on the church to play its part in addressing poverty in a more structured and permanent manner. For example, legislation in the USA challenged the church to take up the plight of the poor with renewed diligence. The USD 500 billion reductions in state spending for 1997-1998 lead Frame (1997:46-49) to ask: 'will the churches, charities and nonprofitable organisations be able to fill the gap?' (see also Cohen \& Waskow 1997). This scenario is also a reality in South Africa. Since 1994 the Department of Social Development of South Africa gradually decreased government subsidies to Nongovernmental organisations (also known as NGOs). Their motivation was that NGOs are independent contractors that have to operate according to their own constitutions. As such the NGOs are not liable to expect financial support from the government, it was argued. According to this view funds that were given in the past should be considered as ex gratia gifts and should not be interpreted as an acknowledgement that the government has a responsibility to financially support NGOs. However, this point of view was repudiated by the Free State High Court in 2002. Furthermore, in 2009 Judge Fouche Jordaan ruled that equity and sustainability are principles imbedded in the South African constitution. This had the implication that it could be expected of the State to make appropriate financial contributions to NGOs. The State had to be forced by law to comply with its responsibility!

The so-called 'emerging church'1 has made repeated accusations that the Church all over the world was either not involved with the plight of the poor, or simply did not do enough. In response to this accusation made by Leonard Sweet, Sandy Simpson responds with a vehement repudiation:

'Where has he (Leonard Sweet) been, anyway, when the major job of feeding the poor has been an ongoing mission of the Christian churches for decades? Who does he think IS doing a good job feeding the poor? UNICEF? United

1.This term refers to a new approach to the church and its responsibilities with Leonard Sweet, Brian McKlaren and Rob Bell being some of the prominent leaders. The emerging church has made great progress in the USA and Europe. 
Way? What a joke. True biblical churches have always reached out to every class of people.'

(Simpson 2010)

Be that as it may, it seems as though the church has heeded the warning and has accepted with renewed commitment the task of caring for the poor. In this regard Du Toit (1997:295) coins the phrase: 'deconstructing poverty talk'. This includes an attack on the existing alibis we have created for the existence and persistence of poverty.

\section{Statement of the problem}

The question arises whether the church is equipped with enough knowledge and skills to develop a more structured approach to the problems surrounding poverty. Previous research (Janse van Rensburg 2009 \& 2010) has indicated that the handouts of soup kitchens, much needed as they are, are simply not enough. In the words of Abraham Lincoln: 'You cannot help men permanently by doing for them what they could and should do for themselves'. This research endeavours to combine the knowledge of theology with the knowledge and experience of other sciences in searching for a structured approach that can empower the church to be more effective in fulfilling her calling. The research is driven by the burning question: 'how could the church increase the effectiveness of its programmes and actions to create an environment that would be more conducive to combatting poverty?'

\section{Hypotheses}

A broad overview of the de facto situation of poverty as well as relevant literature on the topic precipitates a few necessary assumptions to guide this particular research.

The main hypothesis is that pastoral care to the poor requires a long-term approach of caring and counselling. According to Vos (1993:105) the brokenness of people's lives within the context of poverty is so severe and intense that few pastoral counsellors persist with the pastoral process. However, it is precisely the severity of being broken by poverty that necessitates long-term (Clinebell 1987:26) and structured involvement.

Within a sharing relationship between the pastor, the congregation and the people who are poverty-stricken, a pastoral process of healing can take place. It implies that the pastor should spend time with those who suffer. Therefore, a long-term and holistic approach would undoubtedly create the best possible results in terms of healing the wounds caused by poverty, sustaining the poor in their faith during such times of peril and guiding them toward possible solutions or at least to soften the burden for them (Hiltner 1968:64; 89-154). In the final analysis the goal of such an allencompassing (holistic) effort would be to facilitate spiritual growth in relations within the context of poverty. Magezi (2007:11-40), researching the link between poverty and HIV and/or AIDS, stresses the need for a contextual approach, more precisely in the African scenario. Magezi contends that the Church should be in the best position to make the most significant impact on the needs of poor communities, because the Church is the closest infrastructure to the context. When working with communities, accurate information of the context is indispensible. Only unconditional love would enable the pastor to accomplish such a feat, for it would most probably require a time consuming and exhaustive effort. It is therefore essential that caring members of the congregation, who, through their involvement effectively stretch the pastoral process to new limits, should strengthen the efforts of the pastor. Clinebell (1987:14-15) would call these depth-relationships within a caring and nurturing community-programme. In addition, the congregation as nurturing community should provide a loving atmosphere in the worship service in order that poor people also feel welcome and loved (Reed 1997:94).

From this hypothesis three subhypotheses are derived:

- Pastoral care must be accompanied by a structured plan for pastoral care and benevolence wherever possible. This includes the utilisation of different models and approaches to address the many complicated issues as well as the combined efforts of all local churches and institutions.

- Pastoral care and counselling to the poor requires professional skills. This suggests a holistic approach in order to maximise the effectiveness of pastoral care. The knowledge and experience of local governments and individuals are indispensable in this regard.

- A hermeneutic approach (intersubjectivity) is essential in the pastoral care and counselling of poor people. In order to understand the context of poverty we will have to interact with poor people and communities. We have to listen in order to understand. We have to understand in order to help. Kauffman (1997:60) correctly warns that we should stop talking about poor people and engage them in conversation. However, this article will also allow a subject-object or directive approach. This may sound like a contradiction, but Janse van Rensburg (2000) elaborated extensively on the need to use a subject-object approach in extreme situations and unusual contexts.

\section{Describing poverty}

Most researchers are aware of the difficulty involved in trying to define poverty (see Magezi 2007:42-52), therefore it is the assumption of this article that there are many possible solutions to poverty if we could ascertain what kind of poverty we are referring to. Should we address the poverty of knowledge about poverty or should we rather focus on the poverty of sufficient empathy? Although it seems as though there is a move away from attempts to precisely define concepts and phenomena, it could, in light of the aforementioned information, be useful to give some indication of how we understand the concept of poverty. Legislation in South Africa usually commences with concepts like: 'word or concept definitions'. We will follow this example, by trying to explain 'poverty' from Roget's International Thesaurus (2009) as follows. 


\section{Poverty}

Poverty is defined as the condition of being extremely poor: beggary, destitution, impecuniosity, impecuniousness, impoverishment, indigence, need, neediness, pennilessness, penuriousness, penury, privation, and/or want.

\section{Wealth}

Wealth is defined as a great amount of accumulated money and precious possessions: affluence, fortune, pelf, riches, and/or treasure. This includes all things such as money, property, or goods, having economic value (e.g. asset, capital and/or fortune).

The words of Albert Einstein seem to summarise the difference: 'Everything that can be counted does not necessarily count; but everything that counts cannot necessarily be counted'. Keeping Maslow's Hierarchy of Needs from his 1954 book, Motivation and Personality in mind, we can easily see how deprivation of any of the different hierarchies in varying degrees could explain Einstein's remark. We will therefore have to conclude that poverty should be understood as a much broader concept than the standard reference of not having food, clothes and a home. As a holistic approach to poverty and pastoral care has been pleaded (Janse van Rensburg 2010), and because a holistic understanding of human existence is essential (Louw 2000) ${ }^{2}$, it is inevitable that deprivation of any given needs in Maslow's hierarchy could also create or precipitate other needs as the effect of poverty grows in intensity. Addressing poverty could therefore mean an extension of pastoral care to areas of existence not directly linked to or understood as poverty.

\section{Poverty imbedded in the social textures of our country}

Within the context of the paradigm we have explained above, we should now reflect on the social conscience of humans as it is or was contained in many fundamental theories underlying the social structures that caused or aggravated poverty in our country. These fundamentals must be related to the socioeconomic carnage in our country, for poverty is embodied in the social texture of our land. Our personal point of departure will influence our response and interpretation of information about society. This needs further explanation.

\section{An individual's 'map' of the world}

According to Derks and Hollander (1997:53) the map is not the territory. According to them we do not react on the world itself, neither to its territory, but upon our own worldview. We therefore make choices from the in-coming information. This act is performed almost unknowingly according to our worldview.

No human can fully absorb nor fully contain what they see, feel, hear, smell and taste in the world. Therefore each of us continuously generalise information and summarise the

2.Louw dedicates the complete text of his book to a holistic understanding of human existence. impressions that we experience according to a language system referred to as 'representational' systems. What we experience daily is coded and then decoded in accordance with a language system of experiences that has been decoded according to our world view. This process, called 'mapping' is known as the scientific principles of Neuro-Linguistic Programming. A person's map of the world inevitably represents a personalised and subjective map of the world. Our nervous system reacts to our sensory impressions of the world and our experiences. In communication each person then uses some of the elements or types to digest what is seen, heard and felt daily. In discussing or interpreting a person's map of the world each person uses a personal communication system consisting of verbal and nonverbal ways that link up with their 'map' of their world (Derks \& Hollander 1997:53-54).

It is, however, very important to understand that an individual's 'map' will never correspond with 'the real world', the world that consists of all other people's 'maps' of their world - a world outside the confines of that individuals limited view. Reigning above a person's 'map' of their world is a holistic universe of individuals' models of their worlds that is comprised of a coherent mass of consensus in terms of many issues. Although not all people have the same views, skills and talents - individualism allows each person to pursue their own individual destiny in accordance with their priorities. A bigger unity in diversity needs to be encouraged before ultimate convictions are derived at. That 'consensus' is described as a world model. In this regard much has been written about the influence of the so-called 'global village' on the world view (see Graham \& Rowlands 2005).

This of course implies that efforts of sustaining the poor and alleviating their needs would require a very careful listening to and monitoring of the life and world context of those people who are to be the object of our caring and counselling. This point is elaborately stressed by Reinder Kingma and Lotter (2002:328) who in an informative research article discuss mega tendencies that influence life and worldviews. In the search for meaning in existence, particularly in the South African context, pastoral involvement is impossible without true and empathetic understanding of the life context of people in need. How, for example, could we ever make meaningful contributions to addressing the religious, social and economic needs within a drug and crime ridden community like the Cape Flats (Western Cape, South Africa) without a true knowledge and understanding of the forces by which this community is driven? This is made apparent by MacMaster (2007:278-289) as he concludes that individual and pastoral care and psychological paradigms would not be sufficient to address the many and varied challenges of such a community. Listening to the plights of these people without getting involved would not be effective. What is needed 'is the willingness of Christians, pastors or community workers to "walk with" a gangster or gangsters' (Macmaster 2007:288). Pienaar and Van den Berg (2005:99) refer to this need for contextualisation as 'a ground-up contextual Practical Theology' and conclude that a specific worldview 
makes a ground-up view possible (2005:100), illustrating once more the need for Neuro-Linguistic Programming. In the final analysis this illustrates that it is impossible for one model to address all kinds of poverty.

\section{Variables in poverty}

Poverty has many faces. Consider, for example, the following equations:

- $1+1=2$

- $1+1=3$ ?

- $1 \times 0=0$

- $1 \div 0=\infty$ ?

These equations, extremely simple on face value and widely acknowledged, yet more complex than meets the eye, are mathematical expressions of the struggle of many people in our country. They also reflect the true solutions to the deplorable socioeconomic state-of-affairs in South Africa. The equations camouflage the ebbs and flows that are experienced in real life. These pure, but simple figures represent trials, struggles and tribulations sometimes too deep to contemplate. In all of these references the position of the 'observer' is critical. Is the position from where the 'play' is observed in or outside the domain where this brutal contest is contested and decided? The term 'involved observer' (insider researcher) is applicable here. The field of NeuroLinguistic Programming helps us to understand the term 'involved observer':

- To be poor is expensive. Basic commodities have become just too expensive.

- Can the 'church' also be described as poor? Is the 'currency' in which the 'church' is dealing appropriate to deliver its 'mandate' received from God to care for the poor? Or has the church become detached from its commitments refrained in The Battle Hymn of the Republic (Howe; Steffe; $1862 ; 1856)$ 'His truth is marching on?'

\section{The social relevance of the equations}

In the first equation $(1+1=2)$ the consequence of the conscience of two forces in South Africa (one person or group plus another person or group) working toward individual interests, is depicted. The $\sum$ (sum) total of these two equals a normal result that is merely academic, individualistic and based on self-interest. Exclusivity, so often blamed for a lack of involvement in socioeconomic welfare, results in a cold, clinical and texture-less society.

The second equation $(1+1=3$ ?) reflects the managerial or religious principle of synergy, where the combined contributions by both individuals and groups outperforms the previous result by exponential margins. As Capra aptly explains:

The more we study the major problems of our time, the more we come to realise that they cannot be understood in isolation. They are systemic problems that mean that they are interconnected and interdependent.

(Capra 1996:9)
This quantative expression encapsulates the humanity in humanity. The result is caring and compassion.

In the third example $(1 \times 0=0)$ the mathematical expression is related to many unfortunate situations in our country that pertain to this research. What results could be expected where one person or group struggles on her or his or their own to survive, only to be slowly forced, as Frankl (2004:22) reflected, step by step into a struggle for mere survival. Frankl recalls in qualitative narrative:

Then I grasped the meaning of the greatest secret that human poetry and human thought and belief have to impart: "The salvation of man is through love and in love'.

(Frankl 2004:49)

Likewise, Schelling (Nobel Laureate in Economics), proved that, 'if the zero-sum game (chess) - one winner one loser is the limiting case of pure conflict, .... the other extreme is pure collaboration' (nonzero-sum) (1980:84). This is known as coordinated problem solving (see also Section 40 of The Constitution of the Republic of South Africa).

The fourth example $(1 \div 0=\infty$ ?) proves that nothing ' 0 ' isn't really nothing because as physics have proved there isn't really a state of 'nothingness'. Something (pride, strength, hope, resourcefulness, creativity, the example of peoples conduct, attitude, and courage) always remains. Therefore, although humans could be stripped of 'everything', life (circumstances) is not in any position to strip humans of their humanity and the certainty of Christ's love. As Frankl reminds: 'He who has a why to live for can survive almost any how' (2004:9).

This numerical exposition declares that even though the poor and destitute seemingly have 'nothing' (0), there remains, even infinitesimal $(\infty)$ small visions of hope (resourcefulness) for a better tomorrow. In his preface to Frankl's book, Man's search for meaning, professor Allport eloquently raises a theme that is consistently threaded into the pages of the book, namely: "'What remains is the last of human freedoms" - the ability to choose one's own attitude in a given set of circumstances' (2004:9). At the June conference of Technology, Entertainment and Design (TED) ${ }^{3}$ (2006), Anthony Robbins rightfully concluded that the lack of resources does not sufficiently define reasons for a lack of achievement (self-improvement) in people's lives. On the other hand, the application of 'resourcefulness' should then be the main factor that could make a difference in people's lives. The human race can never, except in a state of extreme deficiency, become nothing. In the downward spiral of incremental poverty there remains a will and determination to fight the odds. In his infinite wisdom God created the human race uniquely and resourceful. Amazing stories are abounding where the human race survived the most extreme conditions.

3.TED is a small nonprofit organisation devoted to Ideas Worth Spreading. It started out (in 1984) as a conference bringing together people from three worlds: Technology, Entertainment, Design. The annual TED conferences, in Long Beach/Palm Springs and Entertainment, Design. The annual TED conferences, in Long Beach/Palm Springs and
Oxford, bring together the world's most fascinating thinkers and doers, who are challenged to give the talk of their lives (in 18 minutes). 


\section{The role of Local Economic Development}

Local Economic Development (LED) comprises more than generally meets the eye. To address poverty is to apply the many obstacles and respect the forces that impact on LED. Everything a local government or church institution does, relates to LED. If LED could be made to work effectively, it would impact on the whole of South Africa. The problem however is that societies see local government, church fraternities and welfare organisations as solely responsible for growth and development, including poverty alleviation. However, no local government or church institution can ever hope to conquer poverty on their own. Poverty is a matter of conscience and conscience about the suffering of people should penetrate each layer of society.

How could LED be effective? First and foremost, we need to address the destructive perception that LED is the sole responsibility of local municipalities. To address and to fight poverty, sustained and coordinated efforts must be made visible and tangible. This makes inclusive efforts of all local institutions (including churches) an absolute necessity. Budgets and programmes mean nothing if everyone does not become part of the solution. Poverty alleviation is 'everybody's business'.

\section{Efforts to break free}

Could we assist people to break free from the vicious circle of poverty and its devastating effects? Sacks (2005:51) suggest that to engage in the combat against poverty, we should assist and encourage the poor to increase the economic output per person, also known as the Gross Domestic Product (GDP). Through his research Sacks has found that the transition to economic development in the world began with a rise in GDP. This finding was based on the following assumptions (Sacks 2005:51-53):

- Despite exclusion, the poor retain strong resilience.

- Roads, water, electricity and telephones are critical for reducing the isolation of the poor.

- Initiative and creativity help overcome harsh conditions in search of a better life.

- It is possible to escape poverty but dangerous and easy to fall back.

- Responsive local governments are the key to expanding local market opportunities.

- Generating economic opportunities improve people's chance to accumulate assets

- Imaginative strategies are needed to move from cooperatives to corporations.

If we, for the sake of argument, apply the principles mooted by Einstein and matrix them to Maslow's theory, we find that approximately $63 \%$ of the world's GDP falls into the so-called 'intangible industry' called 'service'. Therefore, the most important truths that can contribute to the alleviation op poverty and the actions that really count cannot be counted and is therefore intangible. Sacks quotes Bhutan's pursuit of GNH 'Gross National Happiness' (an alternative definition of success) to motivate his argument. Things like integrity, quality of education, health of our children, our courage, our will, our compassion, intelligence of our public debate all make up the GNH of our existence. According to president Nicolas Sarkozy of France:

'We're living in one of those epochs where certitudes have vanished ... we have to reinvent, to reconstruct everything. The central issue is [to pick] the way of development, the model of society, the civilization we want to live in.

(Sarkozy 2009)

This means that the 'world model of success-(GDP)' is actually incapable of fully explaining success. If the measurable (tangible) instruments of success do not completely describe and calculate the real and basic essence of how rich or poor a country and its peopleare, how trustworthy is this matrix then? What if the intangible (i.e. truth, justice, wisdom, meaning, recognition, attention, accomplishment and self-respect) become more important than the tangible. This illustrates the intricate web of complications in trying to dismantle poverty. Should we think that poverty is far removed from us and that we will not be touched by its tentacles, God's intent gently and subtly confronts us with situations that force us to consider the world outside ours. In many cases we discover how closely related our world is to a brutal world where the fight for survival is fought every minute of every day. Thus, we become responsible both for the manifestation and the combat of poverty. The question then arises 'do we simply earn what we have created, or do we deserve what we have allowed to come into existence?' The old axiom, that if you prioritise one thing you automatically deprioritise something else, necessitates and enforces involvement.

\section{Some fundamental poverty alleviation mechanisms}

There are so many ways in which individuals and formal institutions can become harmoniously involved in poverty alleviation. Legislation, regulatory frameworks as well as policies wherein 'a better life for all' is featured are abounding in organisations and institutions. However, as a result of the nature and culture of 'society', they more often than not fail to make a marked difference, mostly because of politics and personal gain. Policies, how smart and how well formulated they might be mean nothing if they cannot become a vehicle of improvement. If they cannot facilitate 'a better life for all', they are irrelevant to the final and clinical ethos of Christianity. But if policies could be practically directed towards empowerment, if such policies could be redressed from time to time instead of left in the unchangeable formulations of history, and if efforts are joined instead of fragmented, it could make a big difference. Some of these possibilities will briefly be discussed.

\section{Asset vulnerability audit}

Research in the form of a sample case study amongst nine local government institutions in South Africa conducted by the previous Department of Provincial and Local Government 
in $2003 / 2004^{4}$ revealed that 'asset vulnerability for the poor' featured prominently as one of the fundamental important prognostics in the fight against (at least) curbing poverty. The argument relates the necessity for (at least) preserving the assets of the poor and to guard the latter against loss and resultant replacement.

One of the many important assets that need attention is health. It is in this regard that churches should join forces in voicing protest against the terrible circumstances that are undermining the health of poor people. Examples of these include the devastating effect of the lack of clear and running water on the health of those who suffer from poverty, not to mention the lack of food, access to health facilities and medicine, to name but a few. As an example of the immensity of the problem, it might be helpful to try to calculate the financial impact of medical costs as a result of the provision of medical care in state hospitals and the effect on the local and national economy. Magezi (2007:51-52) highlights that the chances of HIV infection are increased by factors such as homelessness and migration.

Besides the much-needed efforts of congregations and denominations to provide soup kitchens, forces could be joined with other local institutions to improve living conditions within the local community in the effort to protect the all-important asset of health. Congregation members could be encouraged to be more aware of the health hazards that their house and garden workers (with their families) face and make an effort to give as much financial and physical support as they are capable of. ${ }^{5}$

\section{Subsidised transport}

Another tangible way of societal involvement in combating poverty is subsidised transport. The coordinated responsibility of employers to provide or subsidise transport needs to be adressed. Owning one's own transport is a luxury for a great percentage of the population in South Africa. The relevance of this fact has been relayed in the case of transport costs mentioned earlier. To obtain necessary household necessities especially in rural areas is a matter of material existence. If the obtainment of this necessity is influenced by exorbitant travel costs, poverty alleviation is delivered another blow. The impact that transportation exerts on the budgets of workers should not be underestimated. Many need to board up to five taxis to reach their destination and to reach their destination may take up to 3 hours. Imagine what influence that factor has on productivity let alone on the budget of the majority.

\section{Multiplier-effect}

After sincere efforts by National Governmental structures to guide effective local government the National Framework for Local Economic Development (LED) in South Africa

4.Islanda Institute for the Department of Constitutional Development, undated, CTP Book Printers- blg 2002/3, CTP Book Printers.

5.In South Africa it is quite common for people who have middle to higher income, to employ people to clean their houses and tend to their gardens.
(2006-2011) was published. An important objective that has been contained therein reads that:

Annually, government spends billions of Rands a year on its programmes in marginalised areas, but a low income multiplier of only 1.3 stimulates little in the way of development. In the first economy, this income multiplier is between 7 and 12. If the local income multiplier in marginalized areas can be raised to about 4.0, the economic activity derived from government expenditure could be raised substantially, transforming the areas and allowing them to contribute meaningfully to the national economy.

(LED 2006-2011:21)

For the church this scenario presents monitory opportunities to really get hands-on involvement with the plight of the poor. Getting the proverbial 'hands dirty' to improve living circumstances of local communities presupposes much more than small contributions given to alleviate the pressure of a guilty conscience. Would preachers have the courage to preach about fair salaries for their workers? Would congregations venture on projects of improving living conditions in local communities and within their own congregations? Could we really pat ourselves on the back for giving handouts to the poor, whilst those whom we mean to help continue living in the most appalling conditions?

\section{The role and impact of cooperatives}

One of the salient characteristics of a local government's obligatory Spatial Development Framework (SDF) is the systematic linkage of the basic economic sectors with each other. The SDF strives to circulate or link, as basic explanation, the produce to the consumer, thereby impacting on the circulation of money (the so-called multiplier-effect) in a specific geographical area, thereby contributing to the sustainment or creation of jobs. One measure to address poverty alleviation is therefore to enable the 'cooperatives' (some municipalities refer to this economic sector as 'commonage farmers'), as a component of the informal sector, to develop their expertise to such an extent that products harvested by them find their way to the shelves of local major enterprises. Local citizens can become involved by insisting on buying locally produced fresh and other products and to share or deploy their expertise. This could increase the business and other necessary skills of these producers to an extent that their products will favourably compete with that of major corporations. Many congregations have already started garden projects, assisting local communities in planning, executing and developing such projects (Burger, Meyring \& Van Niekerk 2005:78-80). However, much innovation is needed to extend this principle to other joint ventures where training and institution of small business could create jobs and secure even the smallest of incomes. For example, training people to become masons, carpenters, painters, house workers, etcetera, and assisting them in advertising their expertise could assist people to secure an income via small projects. Could congregations start such a service or sponsor poor people who would want to have such training? 


\section{Job creation and preservation}

Poverty is proportionately connected to job creation and preservation. In this process, local communities can assist in determining the real reasons for any employment change in the employment landscape. In the past this aspect of the problem of poverty was considered to be out of bounds for the church. This perception has changed and many churches are currently involved with programmes to assist people in securing jobs. We could, however, do more. Many people without jobs are spiritually and psychologically not ready to take up job opportunities or to keep their job. This is not always because of a lack of motivation to work. They may lack the appropriate skills. Even the lack of self confidence and a low self esteem may be the cause for their refrain from seeking or taking up jobs.

According to Armet (1997:18-22) the lack of viable models for a holistic ministry should be blamed. A holistic model, starting out with evangelism, leads to making disciples. This in turn leads to pastoral concerns, which lead to new social and economic relationships. But how would one be able to evangelise or provide pastoral care and comfort to the poor without providing for the most basic needs of their existence? Verster (1997:160) therefore correctly gives priority to Christian charity above evangelisation, where basic needs are predominant.

Along these lines Frame (1997b:70-72) explains how a 12week Bible study programme prepares poor people for the day when the opportunity of a job presents itself. When this happens, people who attended the programme would be equipped with basic skills on working ethics, attitude and motivation to convince the employer that he or she is the right person for the job. Within a pastoral context, many other issues will almost surely complicate the pastoral process. How does the pastor deal with the despair and frustrations of people who remain in their hopeless position despite their faith that God will provide? What does the pastor say when people find it increasingly difficult to believe in a God that would leave them in their predicament? How does the pastor generate hope when all hope has vanished? And what about the impact that poverty has on family life in general and the marriage in particular? How does the pastor deal with ethical matters arising from poverty? How does the pastoral counsellor deal with his or her own guilt and shame as a result of the fruitless efforts to change the circumstances of the poor (Vos 1993:107-108)? A pastoral approach could contribute largely to a change in attitude.

It is clear that such a pastoral programme would require professional insight and skills in order to maximise the effect of the programme. Where the stressful circumstances of poverty may precipitate psychopathology or psychopathology may be the cause of poverty, the need for professional therapy with a psychologist or psychiatrist should not be excluded. Whenever such professional help is indispensable, a church support system for benevolence should pay for such treatment in order to maximise the effect of the pastoral care. This approach represents a shift from an autonomous, privatised model of therapy to a more inclusive and collegial model of therapy (Vos 1993:105).

\section{Monitoring and evaluation}

The assessment of the success or failure of efforts to empower individuals and communities is imperative. Some religious fraternities are rightfully blaming state for their 'service delivery failures'. But the question then also remains what the track record of spiritual and religious groupings are when their 'service delivery performances' are being assessed according to Biblical standards? In our State's Integrated Social Rural Development Programme (ISRDP) ample mention is made of 'Faith based Organisations'. This implies that the State depends upon the assistance and involvement of the church in serving the community. Is the church empowered to empower the people?

\section{Who is 'the Church'?}

The answer to this question is crucial. We need to become more aware that each individual constitutes the 'church'. But, whatever the understanding of the concept 'the church' in the 22nd century may be, we cannot compartmentalise and delay the responsibility of church institutions and programmes to adapt to the idiom of appropriateness. If the church becomes irrelevant and clings to exclusive viewpoints on the transformation of our country, the church will be sidelined and this important institution will be substituted by instruments that will attack this situation with the means God has instilled and provided.

\section{Compassion builders (UBUNTU)}

South Africans are a generous people. Our country's employed people contribute on average R920 million per month to the alleviation of poverty and development. This amounts to approximately $2.2 \%$ of their income according to the State of Giving survey (2001 census). According to the survey:

- $54 \%$ donate money to welfare or other organisations

- $31 \%$ donate food or other products to the poor

- $17 \%$ give of their time and effort

- The average participant in this survey donated approximately R44.00 per month to welfare purposes. The most of the contributors were convinced to donate because of compassionate factors.

This survey cannot quantify the significant acts of compassion by the employing of part time labour, food, bonuses, and acts of compassion by the adoption of impoverished families, children and donations of love and kindness. In another survey (South Africa - The Good News, April 2008) 3000 respondents, representative of South Africans from all walks of life, were asked to comment on their social contributions in the month preceding their interviews. The results showed that an overwhelming $93 \%$ of respondents had given money, goods or time to a cause, organisation or an individual in the month prior to being interviewed, whilst $80 \%$ of respondents 
gave their money to religious institutions, making faith based philanthropy the single largest component of South African giving.

\section{Ecclesiastic requirements for a structured programme}

In planning and executing effective efforts, the pastoral approach of church communities will have to retain a pastoral character. This is especially true if the church combines efforts with Local Economic Development Programmes. Lack of space allows us only to mention briefly some of the main characteristic.

\section{The character and style of our pastoral approach should reflect God's spirituality of caring}

In the Old Testament, God not only proved that he cared, but he also provided for the poor in his commandments (e.g. Dt 15, 16 \& 26). God's compassion for the poor could be considered to be a major theme in the Old Testament (Hardin 1997:149). Indeed, it is astonishing how many times the responsibility to the poor and God's punishment on the neglect towards the poor is reiterated (Ps 72:13; 82:3; Is $25: 4 ;$ Am $4: 1 ; 5: 11 ; 8: 6$, etc.). His kindness ('chesed') to all was meant to be an example to be followed by his covenant people. From this the charge to show kindness and mercy to others is presented ( $\mathrm{Lk}$ 6:36), whilst it is also emphasised that our spirituality toward the poor should reflect God's attitude toward us. This suggests love, acceptance, compassion and respect (De Klerk 1978:22-24) .

The apostle Paul adds to this that we should show our compassion cheerfully ( $\mathrm{Rm} 12: 8$ ), that is: not with unwillingness. Pastoral care without such spirituality would not only be meaningless but also extremely painful for the people we are supposed to help. Such an approach necessitates a shift from a clinical and objective attitude in counselling to an involved solidarity with the poor. Consideration should be given to the possibility that a clinical approach to pastoral care and counselling may indeed prevent the pastor from an empathetic involvement. (Voss 1993:105-107).

Does such an attitude of compassion also include a preferential option? In an enlightening article Byrne (1993) discusses the implications of God's choice to side with the poor. Taking Nietzsche's resentment toward Christian morality as point of departure, Byrne (1993:215-219) investigates the implications of a preferential choice for the poor and concludes that much of what Nietzsche has said could be accepted. In a self-critical moment Byrne (1993) asks:

Which of us does not, upon reading Nietzsche, call to mind some occasion when ignoble motivations underlay our lofty words and sentiments? Moreover, Nietzsche's writings tend to cast a discomforting light upon many a social movement.

(Byrne 1993:221)

6.Although a dated source, this explanation of the pastoral spirituality has a classical ring to it in pastoral theology.
In contrast, the incarnation of God in Christ proves that God placed himself in relationship to each and every human being (1993:238). In the same vein Pope (1993:242) argues that the preferential option for the poor does not call for a contraction of love but rather an expansion of love. The expansion of God's love toward the poor is proportionate to the degree of need of the poor (Pope 1993:263). This, however, does not exclude a partiality toward the poor, a partiality that is both morally justified and necessary (Pope 1993:245). Such a partiality is based on God's partial choice for the poor, yet it should not reflect the faintest hint of bias against others (see the fourth section of the Confession of Belhar, 1986).

\section{The pastoral process should focus on wholeness and healing}

Jesus reveals himself through the metaphor of the good shepherd. He explains that the purpose of his mission is to lay down his life so that we may enjoy life in its fullness ( $\mathrm{v}$. 10). But what does it mean if it is applied to the predicament of the poor? Life in its fullness should definitely include basic needs for food, clothing and housing. However, as Clinebell (1987:31-34) explains, this suggests abundance in all aspects, dimensions and relations of life. This should be made true by a pastoral process within a context of poverty. In real terms it suggests that abundance could be experienced, even in the absence of basic needs when poor people are guided toward healing in all relationships and dimensions of their lives. To this end the good shepherd will persist in seeking the lost sheep in need (Hartin 1997:157). Thomas (1997:29-30) therefore justifiably refers to the healing power of Psalm 23.

\section{The pastoral process should take place within a congregational context}

In his book A Theology of Pastoral Care (s.a.) Eduard Thurneysen particularly stressed the importance of pastoral care within the context of the congregation. This concurs with 1 Corinthians 12:26: If one member suffers, all suffer. Therefore we all are charged with the responsibility to carry each other's burden (Gl 6:2). This suggests the all important and often discussed issue of lay pastoral care. Clinebell (1987:394-415) considers this to be such an important issue that he devotes a whole chapter to this end in his book.

It should be stressed that the spontaneous involvement with poor people, visiting them, comforting them, sustaining and encouraging them, could be just as effective as structured counselling in terms of meaningful steps toward wholeness. It is the love and caring, the honest compassion of fellow believers and the hospitality toward those who wish to be part of the congregation that could be like healing balm to the bruised and battered soul of the poor. Vos (1993:106) comments that such personal contact may not per se be therapy, yet it could have a powerful therapeutic effect. It is all about healing relationships that create a sense of increased security and acceptance (Thomas 1997:29). However, if lay pastoral care is to be effective in extending the efforts of the pastor, it should be thoroughly planned and structured. A clear sense of purpose and vision, empowering the lay 
people with knowledge and basic skills as well as the necessary structures to support the process, is to be called for (Germond 1995:177-181).

Loving relationships, as the basis of lay counselling, are to be distinguished from power relationships and trading relationships (Wright 1982:42). Within a loving relationship lay people are equipped with the compassion and will to listen without being judgmental. What is therefore needed is a critical solidarity with the poor (Reed 1997:100,104). This qualifies lay people to be assistants even though they may not be professionally trained and qualified (Wright 1982:49). To this end the preaching of the Gospel should serve, exhorting the congregation to a diligent involvement with the plight of the poor. Care should however be taken to ensure that no ulterior motives like personal gain or boosting ones own self worth are present within the involvement with people in need (Wright 1982:21).

\section{Pastoral care should take place within the context of eschatological hope}

Eschatology, as Conradie (1999:307-309) points out, is but one aspect of the Christian faith. Hope is the medium of the Christian faith. Louw (2005:258) defines hope as compliance with the need for imagining, vision, anticipation and the possibilities of a better future. Hope combats hopelessness, the greatest killer of joy and initiative. It contradicts despair, a sickness unto death. The theology of hope does therefore not only go hand in hand with the gospel of Jesus Christ, but is also inseparably linked to pastoral care. This is true because of the promise of Jesus, that his mission is to give back life to people, life in its fullness (Jn 10:10).

Thus, hope is rooted in God's love as revealed in Jesus Christ. Such a pastoral message creates hope. This hope, with love and faith is praised to be enduring (1 Cor 13). However, care should be taken to ensure that the character of hope is not merely restricted to the predicaments and needs of the context. Where forgiveness of sin as the soteriological core of hope is omitted, the true character of hope is destroyed (Conradie 1999:316-317). For it is the soteriological character of hope that constitutes a responsibility towards the limitations and human potential within the context (Conradie 1999:320). As Clinebell notes:

To minister effectively to the multiple forms of human brokenness encountered in pastoral care and counselling, it is essential to have a tough, realistic understanding of human sin and evil.

(Clinebell 1987:58)

Within a situation of poverty, the character of pastoral care should therefore be determined by hope. But how can the pastor create hope by means of the pastoral process? Where should we draw the line between creating hope and leading people into fantasy, creating an imaginary world of make believe? Is hope only focused on softening the burden of poverty, hoping for 'a better world' (Reed 1997:98-99). Within the context of poverty, such hope could easily be politicised. Du Toit (1997:285) rightfully warns against hope rhetoric that promises a better future to the poor by means of technology. What then is hope within the context of poverty? Hope within the context of poverty is not the encouragement to dream of the day when poverty will be changed into wealth. Indeed, hope is not primarily focused on the fulfilment of needs and drives at all. Rather, it creates new perspectives on finding true meaning in existence within the context of poverty. Louw (2004:340-348) introduces an important concept in this regard, referring to the healing dynamics of space. From the vantage point of a theology from below, he chooses to work with a God-concept that emphasise the Immanuel-character of God. God is with the poor, creating space for grace and hope and understanding. This God-given space precipitates hope as a new state of being, that is: the courage to be. Within this framework it is truly possible to be poor and still have human dignity (Mouton 2004:266-277) and a meaningful existence. In this way a theology 'from above', trying to understand why God allows people to be poor and why he does not answer prayers of deliverance, is substituted with a hermeneutical approach of space. Such a theology directly links up with a contextual approach to poverty and to the Neuro Linguistic Programming, which has already been discussed.

Thus, hope is more about attitude and a state of being and less about the fulfilment of immediate needs (getting something). Hope becomes the vehicle for searching and finding meaning in existence. Referring once again to the equations previously mentioned, ' 0 ' isn't really nothing. Thus, Biblical hope and healing works with a holistic understanding of humanity and reality (Magezi 2007:135). It not only searches for alleviation of material needs, but also discloses possibilities for selfunderstanding and healing within the context of a desperate situation (Louw 1997:87-98; 214). The South African story of Tsotsi, which became an award winning 2005 movie directed by Gavin Hood develops this theme of self-realisation through inner healing. Van den Berg and Pudule (2009:516) conclude that Tsotsi, the main character from the movie with the same name, in confronting his own violent nature and deciding to choose reconciliation, is being liberated from the social and political incarceration of his circumstances and healed of inner bitterness and strife. Clearly, a pastoral process of hope creates inner peace, which in turn becomes an image and representation of wholeness (Clinebell 1987:53). Yet, hope also opens up unimaginable possibilities for the future. This two-sidedness of hope or bi-polarity, a term used by Heitink (1998) emphasises the 'already' and 'not yet' of eschatology. Victor Frankl, in his book Man's search for Meaning (2004) gave us the perfect example of seeking the true meaning of life, living within the context of Auswitch. Clearly, this places a responsibility on the shoulders of the pastor to be creative in the pastoral approach toward poverty-stricken people, the goal being to create hope where it is nonexistent. A vast diversity of right brain strategies for pastoral care, counselling and therapy is available, amongst others: imagination; music; hypnotherapy; narrative, homework and art (Janse van Rensburg 1998:56-78). The narrative approach that has become so popular (see the discussions by 
Van Heerden and Kotzé (1997:81-98) and Crafford and Kotzé (1997:99-119)) could also be utilised in both private pastoral counselling and especially in group-care and counselling. The healing power of rituals should most definitely be included in this list. In a qualitative study Thomas (1997:2730) illustrates the value of rituals within an African context. She concludes that rituals can create a sense of power and authority that in turn promotes healing. Furthermore, rituals strengthen bonds of koinonia [communion] and thus bring about a sense of increased security. All these and many other strategies may be used to stimulate hope in the true biblical sense. If hope is to create a positive attitude, we will have to agree with Du Toit (1997:297-299) that we need to address the complacency with which poor people more often than not accept their fate. Creating hope and using right brain strategies would therefore have to include searching for possibilities and means to alleviate poverty and the vicious circle of destruction of people's lives. Empowerment no longer focuses on overthrowing the system, but searching for ways and means to exploit the system. Empowerment through pastoral care and counselling is indeed part and parcel of the victorious dimension of eschatological hope (Louw 1997:85-87). In this sense Louw (2005:258) calls for a theology of liberation, the prophetic task of the church 'to voice the needs of the voiceless and to speak out against oppressive structures which deprive people from their basic rights'.

\section{Pastoral care to the poor should be culturally contextualised}

Thomas (1997) clearly illustrates the value of culture in processes of healing:

A theology of power in South Africa takes seriously the cultural construction of the reality of those most marginalised by dominant structures. It therefore emerges from the lived experience of poor people.

(Thomas 1997:36)

This ethnographical approach to pastoral care works with the contextual realities presented by the different cultures. It should be clear that in South Africa the plight of the poor in a Western culture might reflect important differences in comparison to the struggle of poor Black people. For example, the support systems and structures available to Black people would be considerably weaker than that of developed cultures. Furthermore, the predicament of poor Black people is extended by social problems created by the legacy of apartheid (lack of education and training; a rethinking of the character of 'the struggle' in a post-apartheid South Africa). There is also the tragic fact that AIDS seems to be rampant amongst certain cultures.

These and other important issues are receiving attention from the government, medical and social institutions. The question is whether the church in general and pastoral care in particular is involved enough in order to make a much needed contribution. How could the firm family structures in the Black culture be utilised in pastoral care toward the poor? What role should the pastor play and how involved should he or she be in such cultural matters? These are matters to which not nearly enough attention has been given. Without clear and substantial reasoning on these matters there could be no possibility of contextual pastoral care to the poor. Clearly, an in depth study on the contextualisation of pastoral care towards the poor is called for, a matter that needs much more space and attention than this article can supply. Care should however be taken not to be caught up in a one-dimensional perspective of equalling poverty to Black communities. The new dispensation in South Africa has enriched many Black people whilst some White communities are rapidly being impoverished by the loss of jobs as a result of affirmative action and other causes. According to Langner (2010), poverty amongst White people has increased by $197 \%$ in 2009; 131000 impoverished White families do not have sufficient dwellings and did not benefit from RDP houses; and unemployment in White communities increased by $150 \%$.

\section{Conclusion}

The article was guided by the main hypothesis of a long-term approach to pastoral counselling for poor people. Important as hand outs of food and shelter may be, such approaches lack the ongoing and personal pastoral process. A structured approach to pastoral care suggests assistance in more direct and fundamental ways, involving the expertise of local development projects to ensure a structured change in some areas that are the cause of conditions of poverty. In this way the subhypotheses that were investigated, confirmed the need for a holistic approach to pastoral care, the involvement of Local Economic development and a need to work with poor people and communities in an intersubjective hermeneutic approach.

It is hoped that this research will rekindle the fire of a passion for pastoral care and counselling with poor people. It is expected that poverty will increase in Africa in the very near future, thus worsening an already tragic and desperate situation. The fact that poverty will probably creep into every corner of every society may bring the problem right up to the doorstep of every congregation. Churches and congregations in social and economically sound environments would therefore no longer be able to argue that it is not 'our problem'. If the church wants to be relevant in the world, plans and infrastructures must be put in place to enable the church to cope. For this challenge the church must at all cost be prepared.

\section{References}

Armet, S., 1997, 'Holistic Church Planting Among Latin America's Urban Poor', Urban Mission, 4(14), 17-22.

The Confession of Belhar, 1986, Confession accepted at the Synod of the URC in September 1986, Belhar, Cape Town.

Brainquotes, 2011, Albert Einstein quotes, viewed 23 March 2001, from http://www. brainquotes.com

Burger, C., Meiring, L., Van Niekerk, A. \& Wepener, C., 2005, Waar die kerk werk/ Where the Church works, Lux Verbi, Wellington.

Byrne, P.H., 1993, 'Resentment and the preferential option for the poor', Theological Studies 54, 213-241.

Capra, F., 1996, The web of life, Flamingo, London. 
Carrigan, R.L., 1976, 'Where has hope gone? Toward an understanding of hope in pastoral care', Pastoral Psychology 25(1), 39-53. doi:10.1007/BF01761146

Clinebell, H., 1987, Basic types of pastoral care and counseling, Abingdon Press, Nashville, TN.

Cohen, A. \& Waskow, D., 1997, 'The new sodomites. Memos to Clinton', Tikkun 12(1), 19-20, 79.

Conradie, E.M., 1999, 'An eschatological road map for a new century', NGTT 40(3 \& 4), 307-323.

Crafford, J.D. \& Kotzé, D.J., 1997, "n Narratiewe pastorale terapie met depressiewe persone' [A narrative pastoral therapy with depressed people], Acta Theologica persone' 1 (A 1 (1), 99-119.

Derks, L. \& Hollander, J., 1997, Essenties van NLP [Essences of NLP], Servire Uitgewers, Utrecht.

Du Toit, C.W., 1997, 'Empowerment of the poor. Changing our minds on affluence and poverty', Missionalia 25(3), 285-307.

De Klerk, J.J., 1978, Herderkunde [Pastoral care], N.G. Kerkboekhandel, Pretoria.

Frankl, V.E., 2004, Man's search for meaning, Rider Books, London.

Frame, R., 1997a, 'God in a box?', Christianity Today, 07 April, pp. 46-49.

Frame, R. 1997b, 'Helping the poor help themselves', Christianity Today, 03 February pp. 70-73.

Germond, B., 1995, 'Involvement of the laity', in D. Buchanan \& J. Hendriks (eds.) Meeting the future. Christian leadership in South Africa, Knowledge Resources, Randburg.

Graham, E. \& Rowlands, A. (eds.), 2005, Pathways to the Public Square. Practical Theology in an age of Pluralism, LIT Verlag, Munster.

Hartin, P.J., 1997, 'The poor in the Epistle of James and the Gospel of Thomas', Hervormde Teologiese Studies, 53(1\&2), 146-162.

Heitink, G., 1998, Pastorale zorg: theologie, differentiatie, praktijk [Pastoral care theology, differentiation, practice], Kok, Kampen.

Langner, D., 2010, 'Newsletter', in Helpende Hande [Helping Hands] viewed on 09 January 2011, from, http://www.helpinghandfund.co.za/wp-content/uploads/ hh37 e.htm

Hiltner, S., 1968, Preface to pastoral theology, Abingdon Press, New York, NY.

Howe, Julia Ward, 1862, The Battle Hymn of the Republic, viewed n.d., from www. wikipedia.com

Islanda Institute for the Department of Constitutional Development, n.d., CTP Book Printers- blg 2002/3, CTP Book Printers.

Janse van Rensburg, J., 1998, 'Regterbrein-strategieë vir pastorale terapie' [Righ brain strategies for pastoral therapy], Nederduitse Gereformeerde Teologiese Tydskrif, 39(1\&2), 65-78.

Janse van Rensburg, J., 1999, 'Etiek en pastoraat in hermeneutiese konteks' [Ethics and pastorship in hermeneutical context], Tydskrif vir Geesteswetenskappe 39(2), 158-167.

Janse van Rensburg, J., 2000, The paradigm shift, Van Schaik, Pretoria.

Janse van Rensburg, J., 2000, 'The subject of pastoral care: an epistemological discourse. Kaleidoskoop 2000. Bloemfontein', Acta Theologica, suppl. ser. 37.

Kauffman, R.A., 1997, 'Leaders pursue unity in fighting poverty', Christianity Today, 16 June, pp. 60-61.

Louw, D.J., 1997, Pastoraat as vertolking en ontmoeting [Pastoral hermeneutics of encouter: 'A theological design for a basic theory, anthropology, method and therapy], Kaapstad: Lux Verbi.
Louw, D.J., 2004, 'The healing dynamics of space. Relational and systemic therapy in pastoral care to people suffering from poverty', Dutch Reformed Theological Journal suppl. ser. 45(2).

Louw, D.J., 2005, 'Church within the city or city within the church? Urbanisation as a public challenge to the communion sanctorum', in E. Graham \& A. Rowlands (eds.), Pathways to the Public Square. Practical Theology in an age of Pluralism pp. 251-258, LIT Verlag, Munster.

MacMaster, L.L.M., 2007, 'Social and economic emasculation as contributing factors to gangsterism on the Cape Flats', Scriptura 95, 278-289.

Magezi, V., 2007, HIV/AIDS. Poverty and pastoral care and counselling, Sun Press, Stellenbosch.

Mouton, E., 2004, 'Arm en menswaardig? Perspektiewe op God en menswees in 1 Timoteus 2:8-15' [Poor and dignified? Perspectives on God and being human in 1 Timothy], NGTT. suppl. ser. 45(2).

Pienaar, S. \& Van den Berg, J.-A., 2005, HIV/AIDS, 'Violence and children: a Ground up practical theology from Atteridgeville and Katlehong, South Africa', Practical up practical theology from Atteridgevil
Theology in South Africa 20(1), 96-108.

Pope, S.J., 1993, 'Proper and improper partiality and the preferential option for the poor', Theological Studies 64, 242-271.

Reed, R.L., 1997, 'Worship, relevance, and the preferential option for the poor in the holiness movement, 1880-1910', Wesleyan Theological Journal 32, 80-104.

Reinder Kingma, B. \& Lotter, G.A., 2002, 'Begrip vir die lewenskonteks van mense as ' $n$ vereiste vir pastorale begeleiding' [Understanding of the life context of people as a prerequisite for pastoral guidance], Koers 67(3), 309-328.

Roget, P.M., 2009, Roget's II: The New Thesaurus, viewed 23 March 2011, from http:// education.yahoo.com/reference/thesaurus/

Sacks, J., 2005, The end of poverty. How we can make it happen in our lifetime? Penguin Books, London, UK.

Sarkozy, N., 2009, Sarkozy Adds to Calls for GDP Alternative, viewed n.d., from http:// blogs.wsj.com/economics/2009/09/14/sarkozy-adds-to-calls-for-gdp-alternative/

Simpson, S., 2005, Ding Dong, Ding Dong, Wake Up Leonard Sweet!, viewed n.d., from www.deceptioninthechurch.com/dingdong.html=Website

Thomas, L.E., 1997, 'Constructing a theology of power: Lessons from apartheid', Missionalia 25(1), 19-39.

Thurneysen, E., 1962, A theology of pastoral care, John Knox Press, Virginia, VA.

Van den Berg, J.-A. \& Pudule, J., 2009, 'Negotiating the meaning of film for intercultural pastoral work: Tsotsi and the cry for humanity', NGTT 50 (3\&4), 511-518.

Van Heerden, P.R. \& Kotzé, D.J., 1997, 'Die pastorale gesprek binne 'n narratiewe diakonale pastoraat' [The pastoral conversation in a narrative diaconal pastor], Acta Theologica 17(1), 81-98.

Verster, P. 1997, 'Belewing van die missionêre diakonaat in informele behuisingsgemeenskappe in die Vrystaatse platteland: ' $n$ vergelyking van twee groepe' [Experience of the missionary diaconate in informal housing communities in the rural Free State; a comparison of two groups], NGTT 38(3), 159-170.

Vos, R.W., 1993, 'Pastoral social ministry in the ecosystem of the poor: Breaking through the illusions', The Journal of Pastoral Care 47(2), 100-108.

Wikipedia, 2011, William Steffe, viewed n.d., from http://en.wikipedia.org/wiki/ William_Steffe

Wright, F., 1982, Pastoral care for lay people, S.C.M. Press, London. 